\title{
Investigation on College Students' Net Loan
}

\author{
Yi-Yu WANG \\ North China Electric Power University School of Economics and Management \\ 1978090071@qq.com
}

Key words: Net loan, College students, Key universities.

\begin{abstract}
This paper will describe specifically the number proportion, influencing factors, the amount of money, the frequency of using the net loan platform by the college students, research specifically the related net loan platform such as Ant check later, Jingdongious, ious by stages and so on, so far, the greater progress has been achieved in some 985, 211 key universities in Beijing. Specific data and conclusions will be presented in the paper one by one.
\end{abstract}

\section{Introduction}

In China, the consumption level of diverse regions differ greatly. The family economic conditions of college students from different districts will also inevitably be different, which led to its different level of consumption. Under the impact formed by the contract of the high consumption of social environment and the crowd people and their insufficient economic conditions, it is easy to produce comparing mentality and enjoying psychological for college students with not yet healthy outlook on life and sense of worth, material demands is increasing, but they are lack of the fixed cost of living, so it produces the advanced consumer behavior that loaning from the net loan platform. Although $<<$ The interim measures for the business activity management of network credit information agency $>>$, the depository of net loan platform bank, information disclosure standards, the special rectification program of industry and so on are released sequentially in 2016, which increases the supervision of net loan to some extent, but there are still many imperfections, and the college students are easy to be attracted by the bait of "zero down payment”, "zero interest”, "3 minutes money to account", because they are lack of necessary financial knowledge. Therefore, the net loan platform with characteristic of easy to use, loan rapidly and large amount can easily swoop, seize the market easily, alipay even taking the discounts as bait encourages the students to use Ant check later to pay, which undoubtedly make more students touch the net loan, be accustomed to net loan, and finally they fall into the net loan, can't extricate themselves. On one hand, the college students with immature minds can't balance the needs of cash and material very well, they may act on impulse and don't pay more attention to the following pressure of repayment, they are just too late to regret until the naked consequences are in front of them; On the other hand, some net loan platforms press the payment of debt in the method of intimidation and violence, this illegal behavior did not cause the attention of the relevant departments, leading to it's increasingly fierce, so the event of insulting and murdering mother occurred in recent. Repay the debt is regarded as unquestionable moral truth, but this way is obviously not advisable. Therefore, this paper will discuss the topic from two aspects of students and net loan platform.

\section{The Status that College Student use Net Loan Platform}

The college students of this survey are mainly from Tsinghua University, Beijing Normal University, Central University of Finance and Economics, University of International Business and Economics, China University of Political Science and Law, Beijing University of Posts and Telecommunications, North China Electric Power University and so on.

As the data shows that 23.5\% of the college students in Beijing use Ant check later, Jingdongious, installment loan and other net loan platforms. However, among these college students with net loan, the college students who are not very understanding of the net loan platform account for $29.84 \%$, the college students who don't know that they use the net loan platform account for $21.28 \%$. 
In the 1000 questionnaires, the situation of using net loan of freshman, sophomore, junior, senior is respectively $12.02 \%, 17.6 \%, 39.57 \%$, 38.04\%. The result is obvious, the number of using net loan platform is more and more, it is because that many college students spend much money which is saved from young to old ages without left when they are in freshman year, so the more and more money spent in the future.

The proportion of college students using net loan platform

\begin{tabular}{|l|l|l|l|l|}
\hline & Ant check later & Jingdongious & Ious by stages & Elite loan \\
\hline Freshman & $8.61 \%$ & $4.01 \%$ & $0.80 \%$ & $0.61 \%$ \\
\hline Sophomore & $14.40 \%$ & $4.79 \%$ & $1.20 \%$ & $1.59 \%$ \\
\hline Junior & $31.91 \%$ & $5.96 \%$ & $1.28 \%$ & $3.40 \%$ \\
\hline Senior & $24.03 \%$ & $20.02 \%$ & $1.01 \%$ & $2.01 \%$ \\
\hline
\end{tabular}

Note: $3.1 \%$ of college students use a variety of net loan platform.

Among the college students of using these net loan platforms, $75.74 \%$ of the college students have used Ant check later, 28.09\% of the college students have used Jingdongious, $7.32 \%$ of the college students have used installment loan, $4.68 \%$ of the college students have used Elite loan. From this we can see that the college students mainly use the net loan platforms of Ant check later and Jingdongious.

According to the statistics, $48.94 \%$ of the college students using net loan platform major in the subjects which related with economy, $40 \%$ of the college students choose to loan is because that they want to buy favorite things but they are lack of money in the short term, $44.68 \%$ of the college students choose to loan just for convenience, they can repay the money at once, $32.77 \%$ of the college students are just with a try mentality to loan, $8.51 \%$ of the college students said that the non-subjective factor of Ailpay's automatic deduction led to their loans, $1.26 \%$ of the college students even said that they were attracted by the discount to use the net loan platform. Only 17.02\% of these college students insist on daily book, and the $37.45 \%$ never do the daily book. From this we can see, on one hand, college students' material demands are large, the ability of managing capital is insufficient, on the other hand, the net loan platforms are inducing the college students to loan, it makes many students who do not have demand of loan, go to use the net loan platforms.

These borrowed money of loans, $43.83 \%$ of the college students used to buy electronic products, $40 \%$ of the college students use to buy cosmetics and clothing, and $28.51 \%$ of the college students use to relax themselves and enjoy entertainment, $19.57 \%$ of the college students use to invest the education. This shows that, in many cases, using net loan platform is only in order to get some irrelevant things, therefore, $37.02 \%$ of the students said that if they could go back to the past, they would not choose loan in the same circumstances again.

In fact, for their own loan behavior, 54.04\% of the students did not dare to tell their parents about the matter, in the process of field visits and questionnaires, we found that the use of network loan platform is often affected by the surrounding factors, there are many students affected by the influence of dormitory and family to choose loan. Although among the college students of using net loan platform, $13.19 \%$ of the college students' living expense are overspent per month, $8.61 \%$ of the college students' loan are more than 1000 yuan per month, the frequency that $7.66 \%$ of the college students use the net loan platform is more than 5 times per month, but fortunately, there are still $45.11 \%$ of the college students that their monthly living expenses can be remained $100-500$ yuan, $74.9 \%$ of the college students' loan is limited in $0-500$ yuan per month, $78.3 \%$ of the college students use the net loan platform with 0-2 times in a month, this shows that the college students of Beijing's key universitiesstill have the ability of self-control.

On the way of payment, $63.53 \%$ of the college students repay the loan by the way of saving their living expenses, $28.09 \%$ of the college students repay the loan by the way of doing part-time jobs, $21.28 \%$ of the college students repay the loan under the help of their friends and parents, $11.49 \%$ of the college students use the scholarship wined by their hard study to repay the loan, which is the positive side of the net loan platform, it makes part of students who use the net loan platform 
studyvery hard to repay the loan.

Many students said that there were some problems to be solved, such as the confidentiality of the net loan platform's information need to be improved, the using guidelines and norms are not clear enough, there is suspicion of letting people owe intentionally, and the homogeneity of service is serious, there is no variety of repayment options to be chose, and so on.

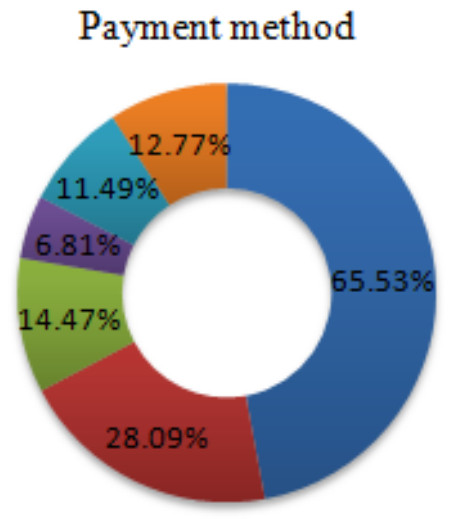

\begin{tabular}{|c|c|c|}
\hline xpenses & Do part time job & Electronic equipment \\
\hline As & Ask friends for help & rtainment \\
\hline $\mathrm{Sc}$ & others & Food \\
\hline
\end{tabular}

Loan purpose

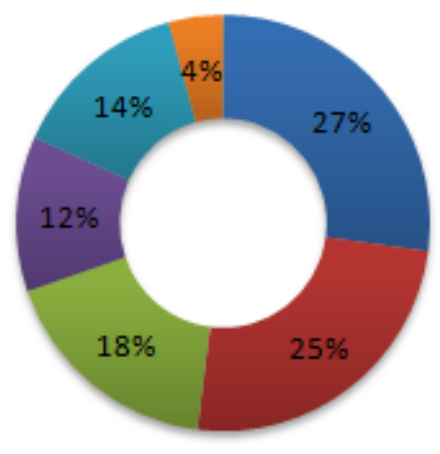

\section{The Data Comparison of Ant Check Later and Jingdongious.}

$90 \%$ of Beijing's college students who loan use Ant check later, Jingdongiousandsuch kind of net loan platforms which is with security guarantee and known to the public, we analysis the situation of these two monopolistic net loan platforms.

Jingdongious launched by Jingdong mall is an Internet consumer financial products which can help consumers get the merchandises first and then pay by installments. The threshold of Jingdongious is very low, can be directly staged. If the users of Ant check later want to repay by stage, their expense must be more than 600 yuan, and they must be compliance with the requirements of credit extension after a large number of data analysis. The credit limit of Jingdongious is $0-15$ thousand. The credit limit of Ant check later is $0-30$ thousand, this is because that the users of Ant check later are filtered.

There are two types of Jingdongious's repayment, one is the 30 days free-interest delay payment, the other is installment in 3-12 months. The fee of installment is $0.5 \%$ per period. The charges of the third term, the sixth term and the ninth term are respectively $1.5 \%, 3 \%, 6 \%$. Users can choose their own installments (3-24 months) or one-off payment method. Overdue users need to pay $0.03 \%$ of liquidated damages to the net loan platforms per day.

The users of Ant check later enjoy the consumer experience of "buy in this month, repay in next month, long time of free-interest”, the consumers can advance the credit limit of Ant check later in consumption, repay the loan in the $10^{\text {th }}$ of next month after confirmation of the goods receipt, the time of free-interest can be as long as 41 days. In addition, there are installments of Ant check latter divided into 3, 6, 9, 12 months. The users must pay the payable account clearly in a certain time, overdue will be charged $5 \%$ of penalty per day.

Jingdongious and Ant check latter will not be limited to their respective Jingdong mall and Taobao. Jingdongious cooperated with Suning Appliance and GOME Appliance and so on enterprise, and Ant check latter has been out of Taobao, involved in Public comment, Dangdang, Xiaomi, OPPO, and so on.

In view of this, the threshold of Jingdongious is lower, but Ant check latter involves a wider range, each has its own merits. They are relatively more secure and less risky than the varieties of college students net loans. However, this does not mean that there is no risk. According to the $196^{\text {th }}$ 
stipulation of $<<$ Criminal Law of the People's Republic of China $>>$, when your overdraft reaches a certain amount, but you still don't repay after 3 times reminder by the issuing bank, you will be charged, once the law believed that your behavior is malicious overdraft or credit bilk, you will assume a fine of more than 20 thousand yuan and a charge of more than 3500 yuan and the follow-up criminal responsibility. In addition to the students themselves, the client will also investigate the family, colleagues, friends, this will affect the basic life of the students, so it is not difficult to understandwhy we see so many students jump off a building, fall into disrepute because of the heavy debt.

\section{The Suggestions for the Current Situation of College Students' Loan.}

In order to prevent students from reckless loans, first of all, the state should enhance the access threshold for college students' loans. At present, China's loan threshold is too low, in order to seize the market and raise the turnover, many net loan platforms reduce the threshold of loans one after another, introduce the simple loan procedures, students can apply for loans on most staging platforms once they provide ID or student's ID. These make the college students' loans more rampant.Secondly, the state should increase the supervision of illegal pressing debt.In order to prevent the debtor from drilling loopholes of the law, the state should make further efforts on improving the legal system of net loan, and implement into real life.Finally, the state should guide college students to establish a correct sense of consumption and worth.Under the condition of market economy, facing the impact of money worship and gastronomy, some college students who love chasing fashion trendy indulge themselves easily in the consumption, the school as the training talents place should guide students to cultivate the correct views of value and consumption, the parents as the students' supervisors also need to give the students the correct guidance of the correct concept of consumption, and timely communicate with students, pay more attention to the student's words and deeds, nip in the bud.

\section{Summary}

In short, facing the problems of students' net loan, the family, school and society need to pay high attention, strengthen guidance and supervision in many ways, the college students themselves also have to enhance the sense of responsibility, loan and consume properly.

\section{References}

[1]Ming-Xu PENG, Jun-Fei ZHANG, Xiao-Jing YANG, Comparison and prevention of risks of Jingdongious and Ant check later,[J].accounting research,2016,(12):74-76.(In Chinese) 